\title{
ANALISIS PROFIL PERSEPSI DAN MOTIVASI BELAJAR DARING SISWA SMK DI KOTA SINGARAJA
}

\author{
Ida Fitria ${ }^{1}$, I Made Candiasa ${ }^{2}$, I Made Sugiarta ${ }^{3}$ \\ ${ }^{1,2,3}$ Fakultas Matematika dan Ilmu Pengetahuan Alam, Universitas Pendidikan Ganesha \\ Email:firida76@gmail.com ${ }^{1}$, candiasa@undiksha.ac.id ${ }^{2}, \underline{\text { made.sugiarta@undiksha.ac.id }}$
}

\section{INFO ARTIKEL}

Riwayat Artikel:

Menerima : 27 September 2020

Revisi : 14 April 2021

Diterima : 26 April 2021

\section{Kata Kunci:}

analisis profil, persepsi, motivasi
Keywords:

profile analysis, perception, motivation

\section{Korespondensi:}

\section{Ida Fitria}

Fakultas Matematikan dan Ilmu Pengetahuan Alam, Universitas

Pendidikan Ganesha

Email:

Fitrida76@gmail.com

\section{ABSTRAK}

Sejak Maret 2020 diterapkan sistem belajar daring. Pengkajian persepsi siswa terhadap belajar daring diperlukan untuk mengetahui tanggapan siswa sehingga tercipta pembelajaran yang bermakna. Belajar daring dilakukan tanpa tatap muka juga perlu dikaji mengenai motivasi belajar siswa untuk mencapai tujuan pembelajaran. Tujuan penelitian adalah untuk mengetahui kedudukan persepsi dan motivasi siswa selama belajar daring sehingga hasilnya bisa dipergunakan untuk perencanaan pembelajaran kedepannya. Pengumpulan data menggunakan data sekunder dari peneliti utama berupa data pengukuran persepsi dan motivasi siswa belajar daring yang diperoleh dari hasil tiga kali pengukuran selama empat minggu dilakukan pembelajaran daring, yakni pengukuran awal setelah dua minggu, dan setelah empat minggu. Analisis data pada penelitian ini adalah analisis profil dengan tiga pengujian hipotesis yaitu uji hipotesis keparalelan, uji hipotesis kesamaan level dan uji hipotesis untuk pengaruh pvariabel utama. Berdasarkan hasil analisis data dapat disimpulkan, kedua pengukuran persepsi dan motivasi paralel, berbeda level, dan ada pengaruh terhadap 3 variabel.

\section{ABSTRACT}

Since March 2020 an online learning system has been implemented. Students' perceptions of online learning need to be researched so that meaningful learning is created. Student learning motivation also needs to be studied because learning is not face to face. The research objective was to determine the position of students' perceptions and motivation during online learning so that the results could be used for planning future learning. The data collection used secondary data from the main researcher in the form of online learning students' perceptions and motivation measurement data obtained from the results of three measurements for four weeks. The data analysis in this study is a profile analysis. Based on the results of the data analysis, it can be concluded that the two measurements of perception and motivation are parallel, have different levels, and there is an influence on 3 variables.

\section{PENDAHULUAN}

Pada abad ke-21 pembelajaran daring telah berkembang sebagai platform di seluruh dunia untuk menghubungkan, berkolaborasi, dan melibatkan pengguna dalam proses pembelajaran (Bhagat dkk., 2016). Sistem belajar dalam jaringan (online learning) atau belajar daring merupakan sebuah bentuk pemanfaatan teknologi untuk mendukung proses belajar mengajar. Menurut Allen \& Seaman (2008), belajar daring adalah pembelajaran dengan sebagian besar konten 
atau semuanya dikirimkan secara online dan dengan proporsi konten disampaikan secara online $80 \%$ atau lebih sehingga pertemuan tatap muka biasanya tidak dimiliki.

Menurut Bhagat dkk (2016) dalam kondisi pembelajaran daring, persepsi siswa perlu untuk diketahui untuk mendorong keterlibatan aktif siswa dan tercapainya pembelajaran yang bermakna. Untuk mengukur persepsi siswa terhadap pembelajaran daring, Hung dalam Bhagat dkk (2016) telah mengembangkan Skala Kesiapan Pembelajaran Online (OLRS) yang mencakup beberapa dimensi penting seperti pembelajaran mandiri, motivasi belajar, efikasi diri komputer/internet, kontrol pembelajar, dan efikasi diri komunikasi online. Beberapa kajian mengenai persepsi siswa belajar daring yaitu bahwa belajar daring memperkuat persepsi siswa tentang pembelajaran serta keterhubungan sosial (Smith, 2013). Pada belajar daring maupun tatap muka perlu untuk memahami arti interaktivitas yang dapat diketahui dari persepsi dari sudut pandang dari narasumber/subjek (Bodnar, 2016). Respon positif diperoleh dari dari persepsi mahasiswa terhadap e-learning yang didasarkan pada data kuesioner (Astuti \& Febrian, 2019). Kemudian berdasarkan hasil survei yang dilakukan oleh IPNU Jawa Timur, diperoleh bahwa mayoritas pelajar ingin metode belajar daring lebih kreatif. Survei persepsi pelajar tersebut bisa dijadikan sebagai referensi bagi pemerintah dalam penentuan kebijakan utamanya dalam bidang pendidikan (NU Online, 2020).
Marganingsih (2013) dalam penelitiannya memperoleh hasil bahwa persepsi mahasiswa terhadap kompetensi sosial guru adalah sangat baik yaitu sebesar $66,5 \%$ dari mahasiswa. Kompetensi sosial guru termasuk di dalamnya yaitu berkomunikasi secara efektif dengan peserta didik. Sejalan dengan penelitan tersebut, Bodnar (2016) mempersepsikan pembelajaran menjadi menarik merupakan diawali dari kontrol guru atas pembelajaran sebagai peningkatan motivasi eksternal.

Kedudukan motivasi memiliki arti penting dalam pencapaian tujuan pembelajaran, motivasi dapat memberikan semangat bagi siswa sehingga dapat mengetahui arah belajarnya (Emda, 2018). Mohamed Ally dalam Bodnar (2016), berpendapat bahwa motivasi internal dan eksternal siswa berkaitan dengan efektivitas pembelajaran daring (online), sehingga pendidik perlu menggunakan berbagai teori pembelajaran yang disesuaikan dengan era digital.

Dalam pembelajaran daring, mengetahui persepsi dan motivasi siswa merupakan hal yang penting. Profil pengukuran persepsi dan motivasi merupakan informasi yang penting untuk mengetahui karakteristik siswa dalam belajar daring. Pemahaman mengenai karakteristik siswa merupakan pijakan utama bagi guru untuk mengembangkan strategi pembelajaran yang optimal (Astuti \& Febrian, 2019). Pembelajaran dapat dilaksanakan secara optimal karena melalui karakteristik siswa yang berbeda-beda, guru pun dapat merancang sebuah pendekatan belajar untuk 
anak didik yang berbeda pula (Sagala, 2010), dan hasilnya dapat digunakan untuk rencana pembelajaran ke depan.

Sejak bulan Maret 2020 siswa belajar dari rumah dalam jaringan (daring). Diperlukan adanya pengkajian tentang persepsi siswa terhadap belajar daring. Persepsi siswa sangat penting dipelajari oleh pelayanan pendidikan, karena perilaku didasarkan pada persepsi mereka (Ningsih dkk., 2018). Selain itu siswa belajar daring dilakukan tanpa tatap muka. Pada belajar daring kontrol dari guru menjadi berkurang (Amilia, 2020) hal tersebut berdampak pada motivasi siswa. Oleh karena itu diperlukan pengkajian mengenai motivasi belajar siswa terhadap belajar daring yang telah dilaksanakan. Untuk mengetahui profil persepsi dan motivasi siswa belajar daring dibutuhkan sebuah analisis. Salah satu analisis yang dapat digunakan yaitu analisis profil.

Analisis profil merupakan bagian dari uji hipotesis terhadap nilai tengah dari peubah ganda yang berkaitan dengan situasi dimana dua kelompok atau lebih dikenakan dengan serangkaian $p$ perlakuan, yang dalam analisisnya digunakan prinsip grafik (Mattjik \& Sumertajaya, 2011). Berdasarkan Agustia dkk., (2013), analisis profil telah diaplikasikan ke berbagai bidang. Seperti pada Annisa (2016) yang menganalisis jenis bahan organik dengan analisis profil untuk mengetahui karakteristiknya dalam menekan kelarutan besi di tanah dan tanaman. Kemudian Agustia dkk., (2013) melakukan perbandingan profil populasi proporsi dari penduduk di Pulau Jawa berdasarkan kelompok umur dengan menggunakan analisis profil. Begitupula pada Nweke dkk.(2019) yang menggunakan analisis profil untuk menentukan tingkat, tren dan perbedaan pada kesuburan di Nigeria.

Dalam pendidikan, analisis profil dianggap sebagai gambaran nilai tes seseorang (Ding, 2000). Menurut Frisby \& Kim (2008) perbedaan antar kelompok dari peserta tes dapat digambarkan melalui analisiss profil yang didasarkan pada pola, skor subtes, maupun konfigurasi unik mereka. Desjardins \& Bulut (2020) mengemukakan bahwa profil skor tes dapat digunakan untuk mengidentifikasi kekuatan akademik dan bidang-bidang yang mudah ditumbuhkan dan dapat digunakan untuk memandu pengembangan intervensi pengajaran atau penempatan siswa, dimana profil siswa diperoleh dari skor yang terdiri dari banyak subtes untuk mengukur kemampuan siswa mengenai kelebihan dan kekurangan siswa dalam keterampilan atau kemampuan tertentu.

Berdasarkan fakta tersebut, peneliti tertarik untuk menganalisis profil siswa berdasarkan pengukuran motivasi dan persepsi siswa belajar daring. Penelitian ini merupakan bagian dari penelitian Prof. Dr. I Made Candiasa, M.I.Komp. dan Dr. Ni Made Sri Mertasari, M.Pd. dengan topik "Model Belajar Siswa SMK selama Proses Belajar dari Rumah". Pengembangan instrumen dan pengumpulan data sudah dilakukan oleh peneliti utama. Penelitian ini hanya berfokus pada penerapan analisis profil data berseri untuk menganalisis profil siswa SMK di Kota Singaraja dari sisi persepsi dan motivasi. 
Berdasarkan uraian di atas, peneliti mengangkat suatu penelitian yang berjudul Analisis Profil Persepsi dan Motivasi Belajar Daring Siswa SMK. Adapun tujuan dalam penelitian ini antara lain: 1) mengetahui apakah profil persepsi dan motivasi belajar siswa SMK di Kota Singaraja selama belajar daring paralel satu sama lain, 2) mengetahui perbedaan profil persepsi dan motivasi belajar siswa SMK di Kota Singaraja selama belajar daring 3) mengetahui pengaruh waktu pengukuran terhadap profil persepsi dan motivasi belajar siswa SMK di Kota Singaraja selama belajar daring.

\section{METODE PENELITIAN}

Penelitian ini menggunakan penelitian studi dokumen pada data sekunder. Tujuan penelitian ini untuk mengetahui profil siswa SMK di Kota Singaraja dalam belajar daring yang dilihat dari sisi persepsi dan motivasi belajar siswa. Untuk mencapai tujuan tersebut digunakan sebuah analisis yaitu analisis profil. Pengumpulan data menggunakan data sekunder yang diperoleh dari penelitian Dr. I Made Candiasa, M.I.Komp. dan Dr. Ni Made Sri Mertasari, M.Pd. pada "Model Belajar Siswa SMK selama Proses Belajar dari Rumah". Data yang digunakan adalah data uji coba terbatas hasil pengukuran persepsi dan motivasi belajar daring terhadap siswa SMK di Kota Singaraja. Kelompok yang dikenakan perlakuan adalah kelompok pengukuran persepsi dan kelompok pengukuran motivasi belajar siswa SMK di Kota Singaraja dengan $p$ perlakuan yang digunakan adalah tiga kali pengukuran secara online selama empat minggu dilakukan pembelajaran daring, yakni di awal (tahap I), setelah dua minggu (tahap II), dan setelah empat minggu (tahap III). Analisis profil memiliki tiga tahapan metode analisis sebagai berikut.

Menguji Keparalelan

Kondisi keparalelan akan menentukkan apakah kedua profil tersebut memiliki kemiringan yang sejajar atau tidak. Kemiringan yang sejajar ini akan menandakan bahwa kedua profil tersebut tidak memiliki interaksi antar populasi dengan variabel yang diuji. Pada pengujian hipotesis keparalelan akan digunakan statistik uji berupa uji Hotelling $T^{2}$ pada dua sampel. Hipotesis yang digunakan adalah:

$$
\begin{gathered}
H_{01}: \mathbf{C} \boldsymbol{\mu}_{\mathbf{1}}=\mathbf{C} \boldsymbol{\mu}_{\mathbf{2}} \\
H_{11}: \mathbf{C} \boldsymbol{\mu}_{\mathbf{1}} \neq \mathbf{C} \boldsymbol{\mu}_{\mathbf{2}}
\end{gathered}
$$

Uji Hotelling $T^{2}$ memiliki nilai statistik untuk dua sampel yang sudah disesuaikan dengan hipotesis pada adalah:

$$
T^{2}=\frac{N_{1} N_{2}}{N_{1}+N_{2}}\left[\mathbf{C}\left(\overline{\mathbf{x}_{1}}-\overline{\mathbf{x}_{2}}\right)\right] \cdot\left(\mathbf{C S C}^{\prime}\right)^{-1}\left[\mathbf{C}\left(\overline{\mathbf{x}_{1}}-\overline{\mathbf{x}_{2}}\right)\right]
$$

dengan $\mathbf{C}$ merupakan matriks kontras ber$\operatorname{ukuran}(p-1) \times p,\left(\overline{\mathbf{x}_{1}}-\overline{\mathbf{x}_{2}}\right) \quad$ adalah matriks selisih vektor rata-rata sampel pertama dan sampel kedua. $\mathbf{S}$ adalah matriks koragam (covarian) dari peubah-peubahnya/ matriks dispersi sampel berukuran $\mathrm{p} \quad \mathrm{x} \quad \mathrm{p}$ yang merupakan peubah tak bias bagi $\sum$ (Mattjik, 2011) 


$$
F=\frac{N_{1}+N_{2}-p}{\left(N_{1}+N_{2}-2\right)(p-1)} T^{2}
$$

$H_{01}$ ditolak bila $F>F_{\alpha ; p-1 ; N_{1}+N_{2}-p}$

Jika $H_{01}$ diterima maka kedua profil tersebut paralel sehingga analisis dapat dilanjutkan ke tahap selanjutnya. Jika $H_{01}$ ditolak maka kedua profil tersebut tidak paralel maka analisis tidak perlu dilanjutkan karena akan sulit diinterpretasikan.

\section{Menguji Kesamaan Level}

Kondisi kesamaan level akan bisa diterapkan jika hipotesis kondisi keparalelan diterima atau memiliki kemiringan yang sejajar. Dari dua proses pengujian hipotesis ada dua kemungkinann yang akan disimpulkan yaitu, kedua profil paralel levelnya sama dan kedua profil paralel namun berbeda level. Hipotesisinya yang digunakan adalah:

$$
\begin{gathered}
H_{02}: \boldsymbol{1}^{\prime} \boldsymbol{\mu}_{\mathbf{1}}=\mathbf{1}^{\prime} \boldsymbol{\mu}_{\mathbf{2}} \\
H_{12}: \boldsymbol{1}^{\prime} \boldsymbol{\mu}_{\mathbf{1}} \neq \mathbf{1}^{\prime} \boldsymbol{\mu}_{\mathbf{2}}
\end{gathered}
$$

Untuk pengujian menggunakan $F$ sebagai perbandingan untuk menyimpulkan hipotesisnya dengan Uji Hotelling $T^{2}$, rumus yang digunakan sebagai berikut.

$$
T^{2}=\left(\frac{\mathbf{1}^{\prime}\left(\overline{\mathbf{x}_{\mathbf{1}}}-\overline{\mathbf{x}_{\mathbf{2}}}\right)}{\sqrt{\left(1 / N_{1}+1 / N_{2}\right) \mathbf{1}^{\prime} \mathbf{S 1}}}\right)^{2}
$$

(Mattjik, 2011)

Setelah mendapatkan nilai statistiknya harus dicari terlebih dahulu nilai $\mathrm{F}$ tabelnya di mana menggunakan $\alpha=0,05$ dan derajat bebasnya $N_{1}+N_{2}-2$ aturan penolakannya adalah:

$$
H_{02} \text { ditolak bila } T^{2}>F_{\alpha ; p-1 ; N_{1}+N_{2}-p}
$$

Untuk menyimpulkan hipotesisnya, jika $H_{02}$ diterima maka kedua profil tersebut memiliki kesamaan level atau bisa disebut sebagai berhimpit dan jika sebaliknya $H_{02}$ ditolak maka kedua profil tersebut paralel dan tidak memiliki kesamaan level.

Menguji Pengaruh $p$ - Variabel Utama

Setelah menguji kesamaan level, selanjutnya akan dilakukan apakah ada pengaruh utama pada $p$ - variabel yang diuji terhadap analisis yang dilakukan. Jika hipotesis yang dilakukan ditolak, maka kesimpulannya adalah terdapat pengaruh utama pada $p$ - variabel yang diuji sedangkan jika hipotesis yang dilakukan diterima, maka kesimpulannya adalah tidak terdapat pengaruh utama pada $p$ - variabel yang diuji. Hipotesisnya adalah:

$$
\begin{gathered}
H_{03}: \mathbf{C}\left(\boldsymbol{\mu}_{\mathbf{1}}-\boldsymbol{\mu}_{\mathbf{2}}\right)=\mathbf{0} \\
H_{13}: \mathbf{C}\left(\boldsymbol{\mu}_{\mathbf{1}}-\boldsymbol{\mu}_{\mathbf{2}}\right) \neq \mathbf{0}
\end{gathered}
$$

Untuk menentukannya digunakan uji Hotelling $T^{2}$. Berbeda dengan uji keparalelan sebelumnya yang menggunakan uji Hotelling $T^{2}$ yang digunakan untuk dua sampel, uji Hotelling $T^{2}$ digunakan untuk sampel tunggal sehingga rumus yang digunakan adalah:

$$
T^{2}=\left(N_{1}+N_{2}\right)(\mathbf{C} \overline{\mathbf{x}})^{\prime}\left(\mathbf{C S C}^{\prime}\right)^{-1}(\mathbf{C} \overline{\mathbf{x}})
$$

dengan,

$$
F=\frac{N_{1}+N_{2}-p}{\left(N_{1}+N_{2}-2\right)(p-1)} T^{2}
$$

Tahap selanjutnya adalah dengan menguji hipotesis di mana aturan yang digunakan 
adalah penolakan $H_{03}$ yang akan dirumuskan sebagai berikut:

$$
H_{03} \text { ditolak bila } F>F_{\alpha ; p-1 ; N_{1}+N_{2}-p}
$$

Jika $H_{03}$ diterima maka profil tersebut tidak memiliki pengaruh utama karena $p$ - variabel. Dan jika sebaliknya $H_{03}$ ditolak maka profil tersebut memiliki pengaruh utama karena $p$ variabel.

\section{HASIL DAN PEMBAHASAN}

Data yang digunakan adalah data pengukuran persepsi dan motivasi siswa belajar daring. Data ini diperoleh dari hasil tiga kali pengukuran selama empat minggu dilakukan pembelajaran daring, yakni pengukuran di awal (tahap I), setelah dua minggu (tahap II), dan setelah empat minggu (tahap III).

Hasil penelitian pada data tersebut akan melalui beberapa tahap yaitu keparalelan, kesamaan level dan pengaruh utama pada $p$ variabel. Pada penelitian ini, data persepsi siswa akan menjadi kelompok pertama di mana $N_{1}=17$ dan motivasi siswa akan menjadi kelompok kedua di mana $N_{2}=17$. Data pada penelitian memiliki 3 variabel penelitian sehingga $p=3$ dengan taraf signifikannya adalah 0,05 .

Menguji Kondisi Keparalelan

$$
\begin{gathered}
H_{01}: \mathbf{C} \boldsymbol{\mu}_{1}=\mathbf{C} \boldsymbol{\mu}_{\mathbf{2}} \\
H_{11}: \mathbf{C} \boldsymbol{\mu}_{\mathbf{1}} \neq \mathbf{C} \boldsymbol{\mu}_{\mathbf{2}}
\end{gathered}
$$

Berdasarkan hasil uji hipotesis untuk menentukan keparalelan diperoleh nilai $F=$ $0.635443<F(0.05,2,17)=3.30$ sehingga $H_{01}$ diterima. Hasil tersebut cocok dengan perhitungan SPSS dan diperoleh nilai signifikan $=0.536>\alpha=0.05$, sehingga $H_{01}$ diterima. Kesimpulan: $H_{01}$ diterima, jadi kedua profil paralel.

\begin{tabular}{|c|c|c|c|c|c|c|}
\hline \multicolumn{7}{|c|}{ Multivariate Tests ${ }^{a}$} \\
\hline \multicolumn{2}{|c|}{ Effect } & $\begin{array}{c}\text { Valu } \\
\text { e }\end{array}$ & F & $\begin{array}{l}\text { Hypoth } \\
\text { esis df }\end{array}$ & $\begin{array}{l}\text { Erro } \\
\text { r df }\end{array}$ & $\begin{array}{l}\mathrm{Si} \\
\mathrm{g} .\end{array}$ \\
\hline \multirow{8}{*}{$\begin{array}{l}\text { Tah } \\
\text { ap }\end{array}$} & Pillai's & & 196.8 & & 31.0 & .00 \\
\hline & Trace & .927 & $59^{\mathrm{b}}$ & 2.000 & 00 & 0 \\
\hline & Wilks' & 073 & 196.8 & ח 200 & 31.0 & .00 \\
\hline & Lambda & $.0 / 3$ & $59^{b}$ & 2.000 & 00 & 0 \\
\hline & Hotellin & 12.7 & 196.8 & & 31.0 & .00 \\
\hline & $\begin{array}{l}g^{\prime} s \\
\text { Trace }\end{array}$ & 01 & $59^{\mathrm{b}}$ & 2.000 & 00 & 0 \\
\hline & Roy's & 12.7 & 196.8 & & 31.0 & .00 \\
\hline & $\begin{array}{l}\text { Largest } \\
\text { Root }\end{array}$ & 01 & $59^{\mathrm{b}}$ & .000 & 00 & 0 \\
\hline
\end{tabular}

Tabel 1. Hasil Pengujian SPSS Kondisi

Keparalelan

Menguji Kesamaan Level

Setelah kedua profil diuji pada pengujian keparalelan ketika kedua profil paralel sehingga dapat dilanjutkan untuk menguji kesamaan level sedangkan jika kedua profil tersebut tidak paralel maka pengujian tidak bisa dilanjutkan ke pengujian kesamaan level maka analisis tersebut selesai. Hipotesis yang akan diuji adalah:

$$
\begin{gathered}
H_{02}: \mathbf{1}^{\prime} \boldsymbol{\mu}_{\mathbf{1}}=\mathbf{1}^{\prime} \boldsymbol{\mu}_{\mathbf{2}} \\
H_{12}: \boldsymbol{1}^{\prime} \boldsymbol{\mu}_{\mathbf{1}} \neq \mathbf{1}^{\prime} \boldsymbol{\mu}_{\mathbf{2}}
\end{gathered}
$$

Berdasarkan hasil uji hipotesis untuk menentukan kesamaan level diperoleh nilai $T^{2}=8.4024774>F(0.05,2,17)=3.30$ sehingga $\mathrm{H}_{02}$ ditolak. Hasil tersebut cocok dengan perhitungan SPSS dan diperoleh nilai signifikan $=0.007<\alpha=0.05$, sehingga $H_{02}$ ditolak. Kesimpulan: $H_{02}$ ditolak, jadi kedua profil populasi terletak pada level yang berbeda. 
Tabel 2. Hasil Pengujian SPSS Kondisi

\begin{tabular}{|c|c|c|c|c|c|c|}
\hline \multicolumn{7}{|c|}{ Kesamaan Level } \\
\hline \multicolumn{7}{|c|}{ Multivariate Tests ${ }^{a}$} \\
\hline \multirow{5}{*}{$\begin{array}{l}\text { Effect } \\
\text { Tahap * } \\
\text { Penguku } \\
\text { ran }\end{array}$} & & Val & & Hypoth & Erro & $\mathrm{Si}$ \\
\hline & & ue & $\mathrm{F}$ & esis df & $\mathrm{rdf}$ & g. \\
\hline & Pillai's & .03 & .63 & \multirow[b]{2}{*}{2.000} & \multicolumn{2}{|c|}{$31.0 \quad .5$} \\
\hline & Trace & 9 & $5^{b}$ & & 00 & 36 \\
\hline & Wilks' & .96 & .63 & \multirow{2}{*}{2.000} & \multicolumn{2}{|l|}{31.0} \\
\hline & $\begin{array}{l}\text { Lambd } \\
a\end{array}$ & 1 & $5^{b}$ & & 00 & 36 \\
\hline & Hotelli & .04 & .63 & \multirow[b]{2}{*}{2.000} & 310 & .5 \\
\hline & $\begin{array}{l}n g^{\prime} s \\
\text { Trace }\end{array}$ & 1 & $5^{b}$ & & 00 & 36 \\
\hline & Roy's & & 63 & \multirow[b]{2}{*}{2.000} & \multirow{2}{*}{$\begin{array}{r}31.0 \\
00\end{array}$} & 5 \\
\hline & Largest & $\begin{array}{r}.04 \\
1\end{array}$ & $\begin{array}{r}.03 \\
5^{b}\end{array}$ & & & 36 \\
\hline
\end{tabular}

Menguji Pengaruh $p$ - Variabel Utama

Setelah memperoleh perhitungan keparalelan dan kesamaan level, langkah selanjutnya adalah mencari perhitungan pengaruh $p$ variabel. Hipotesis yang akan di uji adalah:

$$
\begin{gathered}
H_{03}: \mathbf{C}\left(\boldsymbol{\mu}_{\mathbf{1}}-\boldsymbol{\mu}_{\mathbf{2}}\right)=\mathbf{0} \\
H_{13}: \mathbf{C}\left(\boldsymbol{\mu}_{\mathbf{1}}-\boldsymbol{\mu}_{\mathbf{2}}\right) \neq \mathbf{0}
\end{gathered}
$$

Berdasarkan hasil uji hipotesis untuk menentukan apakah ada pengaruh $p$-variabel utama diperoleh nilai $F=196.85885>$ $F(0.05,2,17)=3.30 \quad$ sehingga $H_{03}$ ditolak.

Hasil tersebut cocok dengan perhitungan SPSS dan diperoleh nilai signifikan $=0.000<\alpha=0.05$, sehingga $H_{03}$ ditolak. Kesimpulan: $H_{03}$ ditolak, jadi ada pengaruh utama 3 variabel penelitian.

Tabel 3. Hasil Pengujian SPSS Kondisi Pengaruh $p$ Variabel

\begin{tabular}{lrccrr}
\multicolumn{6}{c}{ Pengaruh $p$ Variabel } \\
\hline \multicolumn{5}{c}{ Tests of Between-Subjects Effects } \\
\hline Measure: & MEASURE_1 \\
\hline \multicolumn{7}{c}{ Transformed Variable: } & Average \\
\hline \multicolumn{5}{c}{ Type III } \\
Source & Sum of & d & Mean & & Sig \\
Intercept & Squares & $\mathrm{f}$ & Square & F & . \\
& 757835.9 & & 757835.9 & 7830.6 & .00 \\
Pengukur & 22 & 1 & 22 & 48 & 0 \\
an & 813.176 & 1 & 813.176 & 8.402 & .00 \\
& & & & & 7
\end{tabular}

\section{$\begin{array}{llll}\text { Error } \quad 3096.902 & 3 & 96.778 \\ & 2 & 9\end{array}$}

Grafik profil siswa SMK terhadap belajar dalam jaringan (daring) disajikan pada gambar 1 berikut.

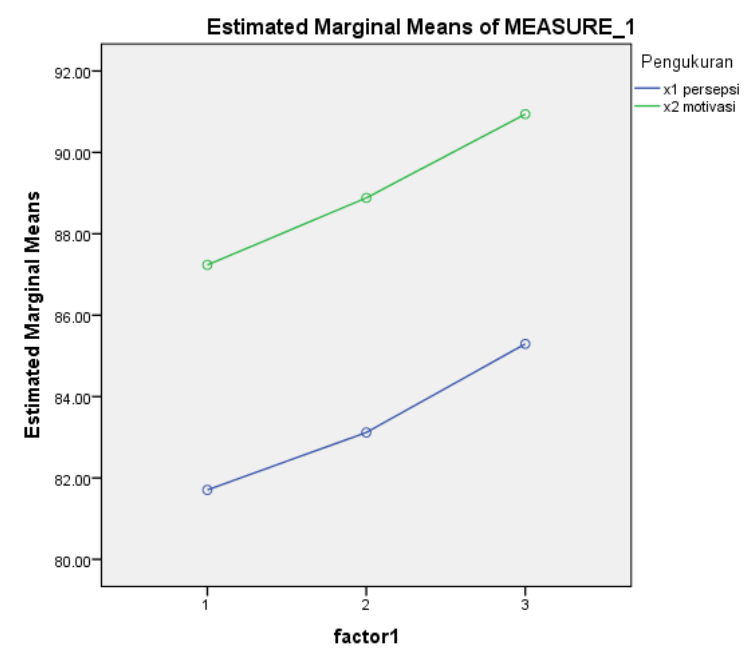

Gambar 1. Grafik Profil Siswa SMK Belajar Daring

Berdasarkan hasil analisis diperoleh bahwa profil siswa belajar daring dari sisi persepsi dan motivasi adalah paralel, berbeda level, dan ada pengaruh utama 3 variabel pengamatan. Profil kedua kelompok menunjukkan paralel atau sejajar menandakan tidak ada interaksi yang signifikan antara kedua kelompok yang diteliti (pengukuran persepsi dan pengukuran motivasi belajar) dan 3 variabel pengamatan yaitu pengukuran di awal (tahap I), setelah dua minggu (tahap II), dan setelah empat minggu (tahap III) (Kusumastuti, 2007; Nweke dkk., 2019).

Profil kelompok persepsi dan motivasi levelnya berbeda atau tidak berhimpit. 
Perbedaan level dapat dilihat dari nilai ratarata seluruh variabel yang diuji dimana pengukuran motivasi memiliki nilai rata-rata yang lebih tinggi (Kusumastuti, 2007) dibandingkan dengan pengukuran persepsi. Dengan kata lain, ada perbedaan yang signifikan antara persepsi dan motivasi.

Pada pengujian pengaruh $p$ variabel diperoleh bahwa terdapat pengaruh utama 3 variabel pengamatan, dengan peningkatan pada masing-masing kedua kelompok. Artinya rataan variabel dalam kedua kelompok tersebut tidak sama untuk setiap kelompok (Agustia dkk., 2013). Ketiga variabel pengamatan tersebut berupa waktu, menandakan bahwa waktu memberikan pengaruh terhadap peningkatan persepsi dan motivasi siswa belajar daring.

Profil persepsi siswa SMK di Kota Singaraja selama pembelajaran daring menunjukkan peningkatan dari tahap 1 sampai dengan tahap 3, yang ditampilkan dalam grafik pada Gambar 4.1. Pada pengujian pengaruh $p$ variabel diperoleh bahwa ada pengaruh utama dari ketiga variabel pengamatan sehingga grafik tidak sejajar sumbu $\mathrm{X}$ menandakan persepsi siswa mengalami perubahan. Perubahan tersebut berupa peningkatan yang terjadi seiring berjalannya waktu dilaksanakannya pembelajaran daring. Peningkatan persepsi ini dapat terjadi karena pada tahap awal dilaksanakannya belajar daring telah tercipta komunitas pembelajaran (Sobron A. N, 2019). Persepsi siswa pada pengukuran pertama memberikan informasi bagi guru sehingga dalam pelaksanakan pembelajaran berikutnya dapat mendorong keterlibatan aktif siswa yang berdampak pada mempersepsikan pembelajaran menjadi menarik(Bodnar, 2016). Persepsi akan timbul karena diawali oleh proses penginderaan. Oleh karena itu agar belajar daring dapat terus memperoleh persepsi yang positif, maka harus dipertahankan pembentukan komunitas pembelajaran dan keterlibatan dari siswa melalui model pembelajaran yang diterapkan oleh guru ke depannya.

\section{SIMPULAN}

Berdasarkan hasil analisis diperoleh bahwa profil siswa belajar daring dari sisi persepsi dan motivasi adalah paralel, berbeda level, dan ada pengaruh utama 3 variabel pengamatan. Pada hasil pengujian keparalelan diperoleh nilai $\mathrm{F}=0.635443<$ $F(0.05,2,31)=3.30 \quad$ sehingga $\quad \mathrm{H} 01$ diterima, jadi kedua profil paralel yang berarti profil persepsi dan motivasi belajar daring siswa SMK di Singaraja mengalami peningkatan dengan proporsi yang sama. Pada hasil pengujian kesamaan level diperoleh nilai $T^{2}=8.4024774>$ $F(0.05,2,31)=3.30$ sehingga $\mathrm{H} 02$ ditolak, jadi kedua profil pengukuran persepsi dan motivasi terletak pada level yang berbeda atau berarti ada perbedaan yang signifikan antara persepsi dan motivasi belajar daring siswa SMK di Singaraja. Pada hasil pengujian pengaruh utama $p$ variabel diperoleh nilai $\mathrm{F}=196.85885>$ 
$F(0.05,2,31)=3.30$ sehingga H03 ditolak, jadi ada pengaruh utama 3 variabel pengamatan, yaitu waktu di mana terjadi peningkatan masing-masing persepsi dan motivasi belajar daring siswa SMK di Singaraja seiring berjalannya waktu. Profil persepsi belajar siswa SMK selama pembelajaran daring mengalami peningkatan rata-rata dari tahap 1 sampai dengan tahap 3. Profil motivasi belajar siswa SMK selama pembelajaran daring mengalami peningkatan rata-rata dari tahap 1 sampai dengan tahap 3.

\section{DAFTAR RUJUKAN}

Agustia, M. H., Usman, M., \& Widiarti, -. (2013). Analisis Profil Populasi Penduduk Pulau Jawa Berdasarkan Kelompok Umur. Prosiding SEMIRATA 2013, l(1). https://jurnal.fmipa.unila.ac.id/semirat a/article/view/904

Allen, I. E., \& Seaman, J. (2008). Staying the Course-Online Education in the United States. 28.

Amilia, D. L. (2020). Menyambut Metode Belajar Normal yang Baru. detiknews. https://news.detik.com/kolom/d4999745/menyambut-metode-belajarnormal-yang-baru

Astuti, P., \& Febrian, F. (2019). Blended Learning Syarah: Bagaimana Penerapan dan Persepsi Mahasiswa. Jurnal Gantang, 4(2), 111-119. https://doi.org/10.31629/jg.v4i2.1560

Bhagat, K. K., Wu, L. Y., \& Chang, C.-Y. (2016). Development and Validation of the Perception of Students Towards
Online Learning (POSTOL). Journal of Educational Technology \& Society, 19(1), 350-359. JSTOR.

Bodnar, A. (2016). Interpreting the HOW of Interactivity in Offline and Online Learning Environments: Perceptions of Interactivity in Offline and Online Learning Experiences to Study Motivations and Engagement in the Context of Today's Participatory Media Landscape. http://lup.lub.lu.se/studentpapers/record/8888037

Desjardins, C. D., \& Bulut, O. (2020). Profile Analysis of Multivariate Data in R: An Introduction to the profileR Package. Journal of Statistical Software, 29.

Ding, C. S. (2000). Profile analysis: Multidimensional scaling approach. 7, 7.

Emda, A. (2018). KEDUDUKAN MOTIVASI BELAJAR SISWA DALAM PEMBELAJARAN. Lantanida Journal, 5(2), 172-182. https://doi.org/10.22373/lj.v5i2.2838

Frisby, C. L., \& Kim, S.-K. (2008). Using Profile Analysis via Multidimensional Scaling (PAMS) to identify core profiles from the WMS-III. Psychological Assessment, 20(1), 1-9. https://doi.org/10.1037/10403590.20 .1 .1

Kusumastuti, A. (2007). Analisis Profil dan Aplikasinya. 155.

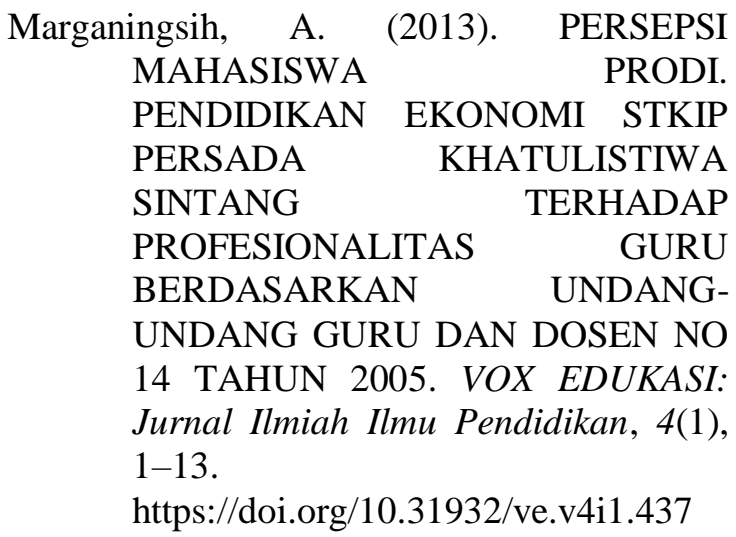


Mattjik, A. A., \& Sumertajaya, I. M. (2011). Sidik Peubah Ganda. 423.

Ningsih, D. A., Imron, A., \& Triwiyanto, T. (2018). HUBUNGAN PERSEPSI TENTANG KUALITAS DAN PELAYANAN PENDIDIKAN DENGAN KEPUASAN ORANG TUA SISWA SEKOLAH MENENGAH KEJURUAN NEGERI. JAMP : Jurnal Administrasi Dan Manajemen Pendidikan, 1(2), 245254.

https://doi.org/10.17977/um027v1i220 $18 \mathrm{p} 245$

NU Online. (2020). Survei IPNU Jatim: Mayoritas Pelajar Ingin Metode Belajar Daring Kreatif. https://www.nu.or.id/post/read/119135 /survei-ipnu-jatim--mayoritas-pelajaringin-metode-belajar-daring-kreatif

Nweke, C. J., Mbaeyi, G. C., Ojide, K. C., \& Okonkwo, C. I. (2019). Fertility Level, Trend and Differentials in Nigeria: A Multivariate Analysis Approach. American Journal of Applied Mathematics and Statistics, 7(6), 231236. https://doi.org/10.12691/ajams-76-5

Sagala, S. (2010). Konsep dan makna pembelajaran. Bandung: alfabeta.

Smith, N. V. (2013). Face-to-face vs. Blended Learning: Effects on Secondary Students 'Perceptions and Performance. Procedia - Social and Behavioral Sciences, 89, 79-83. https://doi.org/10.1016/j.sbspro.2013.0 8.813

Sobron A. N, B. (2019). PERSEPSI SISWA DALAM STUDI PENGARUH DARING LEARNING TERHADAP MINAT BELAJAR IPA. SCAFFOLDING: Jurnal Pendidikan Islam Dan Multikulturalisme, I(2), 30-38.

Wahida Annisa. (2016). Analisis Profil Pengaruh Bahan Organik terhadap
Konsentrasi Besi Ferro dan Serapannya di Lahan Rawa Pasang Surut. Informatika Pertanian, 25(2), 241-248. 